THE KURILLIAN KNOT 



\title{
The Kurillian Knot
}

\author{
A History of Japanese-Russian \\ Border Negotiations
}

HIROSHI KIMURA

Translated by Mark Ealey

Stanford University Press

Stanford, California 


\section{Stanford University Press}

Stanford, California

English translation (C)2008 by the Board of Trustees of the Leland Stanford Junior University. All rights reserved.

Updates and additional material by the author (C)2008 by the Board of Trustees of the Leland Stanford Junior University. All rights reserved.

The Kurillian Knot was originally published in Japanese in I993 under the title Nichiro Kokkyo Kosho Shi (C) I993, Chuo-koran-sha, Tokyo.

The book was published in Russian in 1996 under the title Kuril'skaia problema: Istoriia iapono-rossiiskikh peregovorov po pogranichinym voprosam (C) I996, Iurinkom, Kiev.

The updated and expanded edition of the book was published in Japanese in 2005 under the title Shinpan [revised new edition] Nichiro Kokkyo Kosho Shi (C) 2005 , Kadokawa-shoten, Tokyo.

No part of this book may be reproduced or transmitted in any form or by any means, electronic or mechanical, including photocopying and recording, or in any information storage or retrieval system without the prior written permission of Stanford University Press.

Printed in the United States of America on acid-free, archival-quality paper.

Library of Congress Cataloging-in-Publication Data

Kimura, Hiroshi, 1936-

[Nichi-Ro kokkyo koshoshi. English]

The Kurillian knot : a history of Japanese-Russian border negotiations /

Hiroshi Kimura ; translated by Mark Ealey.

p. cm.

Originally published in Japanese under the title: Nichi-Ro kokkyo koshoshi, I993.

Published in Russian under the title: Kuril'skaia problema, I996.

Includes bibliographical references and index.

ISBN 978-0-8047-5835-2 (cloth : alk. paper)

I. Japan-Boundaries-Russia (Federation)-History. 2. Russia (Federation)Boundaries-Japan-History. 3. Japan-Boundaries-Soviet Union-History. 4. Soviet Union-Boundaries-Japan-History. 5. Kuril Islands (Russia)International status-History. 6. Japan-Foreign relations-Russia (Federation) 7. Russia (Federation)—Foreign relations-Japan. I. Ealey, Mark. II. Title. DS849.R7K534I3 2007

Typeset by Classic Typography in I0.5/12 Bembo 
To my two mentors, Professors Masamichi Inoki and

John N. Hazard 
